\title{
Influence of cheese-making recipes on the composition and characteristics of Camembert-type cheese
}

\author{
Danton Batty, Joy G. Waite-Cusic, ${ }^{*}$ and Lisbeth Meunier-Goddik \\ Department of Food Science and Technology, Oregon State University, Corvallis 97331
}

\section{ABSTRACT}

Bloomy rind cheeses, including Camembert and related varieties, can be produced using alternative processes that vary based on milk preacidification, cutting, curd handling, and ripening parameters. Modification of these parameters creates distinct cheeses such as lactic curd, stabilized curd, and hybrids of the two. The objective of this study was to determine the influence of 5 Camembert-type cheese recipes on the composition and characteristics during ripening. Five varieties of Camembert-type cheese were produced: (1) lactic curd, (2) sweet curd, (3) washed curd, (4) solubilized curd, and (5) stabilized curd. Cheeses were aged at $13^{\circ} \mathrm{C}$ for $10 \mathrm{~d}$, during the mold growth phase, and $7^{\circ} \mathrm{C}$ from $\mathrm{d} 11$ until 50. Key quality metrics including texture development, $\mathrm{pH}$ (center and surface), and color were monitored throughout shelf-life. Compositional evaluation (d 5; fat, protein, moisture, salt, and minerals) grouped cheeses into 3 categories: (1) lactic curd, (2) sweet and washed curd, and (3) solubilized and stabilized curd. The lactic curd and stabilized curd were consistently the most different varieties for composition and quality metrics. Moisture content of Camembert-type varieties ranged from 53.15 to $57.99 \%$, Ca ranged from 0.23 to $0.45 \%$, and $\mathrm{P}$ ranged from 0.21 to $0.40 \%$. All varieties followed the expected $\mathrm{pH}$ evolution on the rind and in the paste with the $\mathrm{pH}$ of the rind reaching 7 by $\mathrm{d} 10$, and paste $\mathrm{pH}$ reaching 7 between 35 and $50 \mathrm{~d}$. The displacement of the paste (distance traveled upon cutting) for the lactic curd was the greatest among the 5 varieties, reaching an average of $27 \pm 1.9 \mathrm{~mm}$ (mean \pm standard error) after $50 \mathrm{~d}$ of ripening and $60 \mathrm{~min}$ of flow time. The stabilized curd on the other hand traveled the shortest distance, reaching an average of $4 \pm 0.4 \mathrm{~mm}$ at the same time point. Browning, considered a defect in mold-ripened cheeses, was observed in all varieties, but was most substantial for lactic curd (lightness, L*, decreased from 87.19 to 68.58 ). Based

Received April 21, 2018.

Accepted September 12, 2018.

*Corresponding author: joy.waite-cusic@oregonstate.edu on these quality metrics the shelf-life of these recipes was estimated with the lactic curd having the shortest, and the stabilized curd having the longest. Examining Camembert-type cheese quality metrics for these 5 varieties can assist cheesemakers during recipe formulation and selection of cheese-making practices to achieve optimum product quality.

Key words: mold-ripened cheese, stabilized cheese, shelf-life

\section{INTRODUCTION}

Soft, bloomy rind cheeses, predominantly Camembert- and Brie-type cheeses, compose a small, but significant, segment of the total cheese market in the United States. Forty-seven percent of the cheesemakers within the American Cheese Society produce surface mold-ripened cheeses (American Cheese Society, 2016; Rebecca Orozco, American Cheese Society, Denver, $\mathrm{CO}$, personal communication). In the past decade, specialty cheese production volumes greatly increased. From 2005 to 2015, the annual production of specialty cheese in Wisconsin (the leading state of specialty cheese production) doubled from 164 to 328 million $\mathrm{kg}$ (Wisconsin Milk Marketing Board, 2017). Grocery sales for Camembert- and Brie-type cheeses increased by $4.7 \%$ from 2004 to 2005, totaling 4.9 million kg annually (Buragas, 2006). This increase in availability and sales of specialty cheese is in part due to the increasing number of artisan cheesemakers. In Oregon alone, the number of artisan specialty cheese processors has experienced significant growth from 3 in 1999 to 26 in 2013 (Bouma et al., 2014). An increase has also occurred on a national level, with the American Cheese Society (2018) reporting a membership increase from 1,418 to 1,831 over the last decade (2007 to 2017).

Soft ripened cheeses were traditionally manufactured in France using basic soft cheese-making practices (Shaw, 1981). Key characteristics for soft ripened cheese processes are the fermentation of cheese milk by mesophilic lactic acid bacteria to a low $\mathrm{pH}(<4.6-5.2)$ with an absence of both cooking and pressing steps. This category of cheeses can be broken into 2 subcategories 
based on rind development: washed rind and bloomy rind. Camembert and Brie belong in the bloomy rind cheese category.

Camembert and related bloomy rind varieties are known for possessing a white/gray rind that is formed as Penicillium candidum, and yeasts such as Geotrichum candidum, Debaryomyces hansenii, and Kluyveromyces spp. grow on the surface of the cheese (Gripon, 1997; Leclercq-Perlat, 2011; Galli et al., 2016). Soft ripened cheeses that undergo transformation by surface molds are unique because of the many physiochemical and biochemical changes that occur over the brief period of ripening (typically $3-5 \mathrm{wk}$ ). These reactions transform a chalky, crumbly, and firm cheese into one that is soft, viscous, and flowing (Lawrence et al., 1987; Sousa, 2003; Tansman et al., 2017). Cheese softening for surface-ripened varieties can be partly explained by mineral migration from the center to the surface of the cheese. This results in the swelling and hydration of the protein matrix (Lucey and Fox, 1993). The mineral migration phenomenon is primarily a result of the $\mathrm{pH}$ increase caused by enzymatic activity from the surface molds (Le Graet et al., 1983; Karahadian and Lindsay, 1987; Tansman et al., 2017).

The optimum time frame for consumption of Camembert-type cheese is between 3 and 7 wk postproduction (Galli et al., 2016). Therefore, getting the cheese to market and consumers is a significant challenge for manufacturers of traditional Camembert-type cheeses with large distribution networks. Camembert-type cheese can be consumed outside of this optimum quality window; however, defects will be noticeable and often unpleasant. These defects include (1) flavor: being overly ammoniacal, sulfury, or bitter, (2) texture: having an overly runny paste, and (3) appearance: deterioration of rind color (browning).

Manufacturers have modified cheese-making practices to lengthen the window of optimum quality and create stabilized bloomy rind cheeses (Lawrence et al., 1987). Stabilization of the paste is primarily accomplished by controlling the rate and level of acid development during draining for a final $\mathrm{pH}$ after draining $\geq 5.2$ (Gripon, 1997). These modifications lead to a young cheese with a softer and more elastic texture, but one that retains physical integrity throughout ripening. Cheesemakers have modified many manufacturing steps to produce stabilized cheeses, including starter selection (i.e., lactic acid bacteria species and strain choice), fermentation time/temperature, target rate and degree of acidification, cut size, and curd handling practices (Lawrence et al., 1987; Gripon, 1997); however, data demonstrating the effect of these modifications on Camembert-type cheese composition and quality characteristics throughout ripening are limited.
The objective of this study was to investigate the influence of 5 commonly used cheese-making recipes on the composition, quality characteristics, and shelf-life of Camembert-type cheese. These 5 varieties capture many of the procedural differences used to manufacture bloomy rind cheeses in the industry. We hypothesize that these 5 common recipes will produce Camemberttype cheeses that differ in composition and rate of ripening as indicated by reduction in firmness and stability of the cheese paste. The goal of this study was to provide recipe information and Camembert-type cheese characteristics of each variant to assist artisan cheesemakers in appropriate recipe selection to achieve optimum quality and extend shelf-life as appropriate for their distribution channels.

\section{MATERIALS AND METHODS}

\section{Overall Experimental Design}

Five different Camembert-type cheese varieties (lactic curd, sweet curd, washed curd, solubilized curd, and stabilized curd) were manufactured. Differences in manufacturing procedure for the 5 varieties are summarized in Table 1. Each variety was manufactured on 2 different days $(\mathrm{n}=2)$. Two cheese wheels from each cheese make were sampled for composition and 3 wheels were sampled for physical characteristics at each time point for analysis.

\section{Cheese Making}

Pasteurized whole milk (average protein-to-fat ratio of $0.97 ; 25 \mathrm{~kg} /$ batch) was supplied by a regional milk processor and transported to the Arbuthnot Dairy Center at Oregon State University (Corvallis) for cheese making. The milk was placed in a round cheese vat (C. van't Riet Dairy Technology B.V., Nieukoop, the Netherlands) and warmed to the appropriate fermentation temperature for the recipe (Table 1). A thermophilic starter culture, Streptococcus thermophilus (Choozit DVI TA 50 series, Danisco, Copenhagen, Denmark), or a mesophilic starter blend (Flora Danica-DVS, Chr. Hansen Inc., Milwaukee, WI), was added to the milk as determined by recipe (Table 1 ). The ripening cultures [Penicillium candidum (PCA 3, Chr. Hansen Inc.), Geotrichum candidum (Choozit Geo 15 LYO, Danisco), and Kluyveromyces marxianus (LAF 4, Chr. Hansen Inc.)] were added to the milk at a rate of $0.40,0.15$, and $0.15 \mathrm{U} / 100 \mathrm{~kg}$, respectively. When preparing the stabilized curd variety, an adjunct culture, Leuconostoc mesenteroides ssp. cremoris (Choozit LM 57, Danisco), was added at rate of $0.73 \mathrm{U} / 100 \mathrm{~kg}$ to enhance flavor development. Except for the lactic curd variety, cal- 


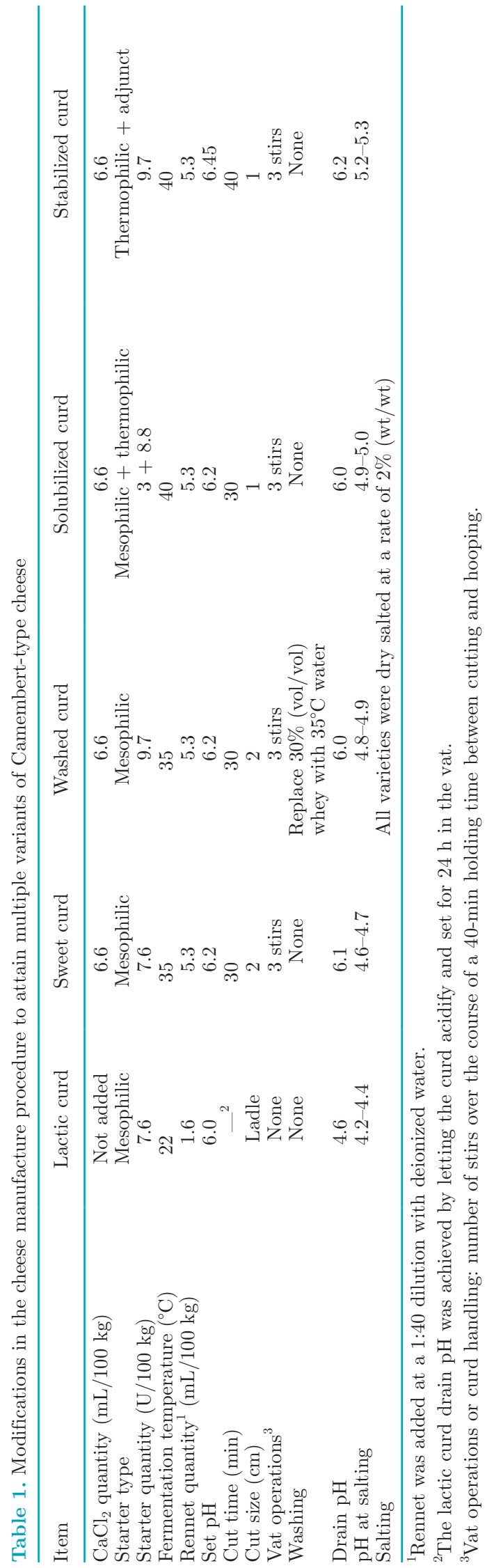

cium chloride (DCI Calcium Chloride, 32 to $33 \%$ wt/ vol, Dairy Connections Inc., Madison, WI) was added during fermentation at a concentration of $6.6 \mathrm{~mL} / 100$ $\mathrm{kg}$. The milk was fermented until the desired set $\mathrm{pH}$ was achieved (Table 1).

For all varieties, excluding the lactic curd, rennet (see concentration in Table 1; DCI Star Coagulant, Dairy Connections Inc.) was stirred gently into the fermented milk and the mixture set for 30 to $40 \mathrm{~min}$ before cutting with either 1- or 2-cm knives (Servi Doryl, Langeais, France). The cut time and size used for each cheese type is shown in Table 1 . The cut time was determined by visual assessment of the gel firmness and flocculation time using a multiplication factor of 5. After cutting, the vats were drained and the forms (Fromagex, Rimouski, Québec, Canada; $7 \mathrm{~cm}$ in diameter) were filled using a curd distributor (Fromagex). For the lactic curd variety, rennet was added once the desired set $\mathrm{pH}$ was achieved (Table 1). Once the lactic curd variety achieved the desired cut $\mathrm{pH}$, it was ladled into the cheese molds over the course of 2 to $3 \mathrm{~h}$. Each mold was filled with curd every 30 to $45 \mathrm{~min}$ for 6 to 7 passes, until the molds were filled. Forty molds were filled for each replicate cheese make with an average cheese weight of $95 \pm 10 \mathrm{~g}$ at salting.

Cheeses were drained at $23 \pm 1^{\circ} \mathrm{C}$ with turning at $30 \mathrm{~min}$ and 5, 10, and $19 \mathrm{~h}$. The cheeses were removed from the molds at either 20 or $24 \mathrm{~h}$ and salted with $2 \%$ salt (wt/wt) and open air-dried for an additional 1 to $2 \mathrm{~h}$. This marked d 0 (start of ripening) for all downstream sampling points. Cheeses were transferred to an incubator $\left(15 \pm 1^{\circ} \mathrm{C}, 85 \%\right.$ relative humidity) for $24 \mathrm{~h}$. The relative humidity was then increased to $95 \%$ and temperature decreased to $13 \pm 1^{\circ} \mathrm{C}$ for 10 $\mathrm{d}$, and cheeses were flipped daily to develop surface mold. Cheeses were then wrapped in white mold paper (Fromagex) and stored at $7 \pm 1^{\circ} \mathrm{C}$ for up to $40 \mathrm{~d}$. After wrapping, cheeses were flipped on d 14, 21, 35, and 50 postmanufacture.

\section{Composition and Physiochemical Analysis}

Milk Composition. Compositional analysis (fat, protein, lactose, and SNF) of milk samples was conducted using a milk analyzer (Lacticheck-01, RapiRead, Hopkinton, MA) before culture addition on the day of cheese manufacture.

Cheese Composition. Cheese samples were collected after $5 \mathrm{~d}$ of ripening (before development of surface molds) for macrocomponent analysis (fat, protein, moisture, minerals). Whole cheese wheels $(\sim 90 \mathrm{~g})$ were homogenized by blending until the size of the cheese particles were uniform $(\sim 15 \mathrm{~s})$. Fat was measured according to the Gerber Van Gulik method (ISO, 2008). 
Protein was estimated using a combustion analyzer (vario MACRO cube, Elementar Analysensysteme GmbH, Hanau, Germany) for total nitrogen determination according to the Dumas combustion method (Wiles et al., 1998). Crude protein was determined by multiplying total nitrogen by 6.38. Moisture content was determined using a rapid moisture and solids analyzer Computrac Max 4000XL (Arizona Instrument LLC, Chandler, AZ). For elemental analysis (Ca, P, $\mathrm{Na}) 10$ sub-samples were taken from each wheel and dried at $35^{\circ} \mathrm{C}$ for $96 \mathrm{~h}$. The samples were then ground with a mortar and pestle. The samples were wet-ashed with nitric acid (Macron Fine Chemicals, Center Valley, PA) using microwave digestion (MultiwaveGO, AntonPaar USA, Ashland, VA). Analysis was performed by inductively coupled plasma atomic emission spectroscopy (ICP-OES: Optima 2100 DV, Perkin Elmer, Waltham, MA) operated using the radial view mode. Total nitrogen and elemental analysis was conducted by the Collaborative Analytical Laboratory (Oregon State University, Corvallis).

Texture Analysis. Texture was analyzed by penetrometery throughout ripening using a modified method previously described by Abraham et al. (2007). A texture analyzer TA XT2i (Texture Technologies Corp., Hamilton, MA) was equipped with a 5 - $\mathrm{kg}$ load cell and a 6 -mm cylindrical probe. The analysis was performed on 3 cheeses from 2 replicate cheese makes on d 7, 14, 21,35 , and 50 postmanufacture. The cheese was tempered to room temperature $\left(22 \pm 1.5^{\circ} \mathrm{C}\right)$ for $1 \mathrm{~h}$ before testing. Axially penetration was accomplished at a rate of $0.4 \mathrm{~mm} / \mathrm{s}$ with the penetration depth set at $75 \%$ of the total cheese height. Firmness of the cheese paste was recorded at the minimum peak and maximum peak within the paste. The paste firmness was determined to be the measurements observed after the initial fracture peak that was due to the rind breaking.

$p H$. The $\mathrm{pH}$ measurements for all in-process and ripening samples were taken using a portable $\mathrm{pH}$ meter equipped with a conical penetration probe designed for measuring semi-solid and solid food products (Portable Food and Dairy pH Meter, Hanna Instruments, Woonsocket, RI). The $\mathrm{pH}$ of the rind was measured daily for the first $10 \mathrm{~d}$ of ripening and throughout total ripening (d 14, 21, 35, and 50). At each sampling time, 3 cheeses were measured in 6 locations. The sampling locations were arranged in a triangle pattern at an equal distance apart on the top and bottom of the cheese wheel. The $\mathrm{pH}$ of the center paste was measured on d 7, 14, 21, 35 , and 50 postmanufacture. The $\mathrm{pH}$ was measured for 3 replicate cheeses for duplicate cheese makes through ripening.
Color. The color of the rind was measured using a spectrophotometer (LabScan XE Spectrophotometer, Hunter Associates Laboratory Inc., Reston, VA). All color measurements were performed on 3 separate cheeses for duplicate cheese makes of the rind throughout ripening, 14, 21, 35, and $50 \mathrm{~d}$ postmanufacture.

Paste Displacement. The stability of the cheese paste was measured quantitatively by measuring the distance the paste traveled from the cut rind of the cheese wheel. On d 35 and 50, 3 cheeses for each cheese make were removed from $7^{\circ} \mathrm{C}$ storage, unwrapped, cut in half, and left undisturbed at ambient temperature for $60 \mathrm{~min}$. Paste displacement $(\mathrm{mm})$ was measured from the edge of the cheese rind to the farthest point of displacement after 15, 30, 45, and 60 min.

Data Analysis. The data were analyzed using JMP Pro 13.0 (SAS Institute Inc., Cary, NC). Means and standard errors were calculated for duplicate $(\mathrm{n}=2)$ cheese makes for composition and shelf-life characteristics. Comparison of means for significance $(P<0.05)$ was conducted using Tukey's honestly significant difference.

\section{RESULTS}

\section{Compositional Analysis}

Milk. The average composition of the milk used to manufacture Camembert-type cheese over 2 separate days comprised of $3.57 \%$ fat, $3.48 \%$ protein, $5.05 \%$ lactose, and $9.22 \% \mathrm{SNF}$. The average protein-to-fat ratio was 0.97. Protein and SNF of milk differed significantly $(P<0.05)$; however, protein-to-fat ratio of the milk did not vary significantly.

Cheese Composition. Complete Camembert cheese composition for each variety is shown in Table 2 . Variation in the 5 cheesemaking recipes resulted in significant differences in most of the compositional components analyzed in this study. The Na (dry basis; $0.94-1.04 \%$ ) was the only analyte that did not differ significantly by recipe. Based on overall compositional comparisons, the 5 Camembert varieties can be organized in to 3 separate groups. These groupings are (1) lactic curd, (2) sweet curd and washed curd, and (3) solubilized curd and stabilized curd. These groupings shared comparable manufacturing recipes.

Compositional analysis demonstrated that the lactic curd cheese was the most different from the other varieties. The lactic curd cheese is acidified for up to 24 $\mathrm{h}$, and is ladled in large pieces rather than cut, which results in the highest moisture cheese $(57.99 \%)$ with the lowest protein $(15.43 \%)$, fat $(21.75 \%)$, salt $(1.05 \%)$, 
Table 2. Composition expressed as $\%$ weight of cheese for 5 different varieties of Camembert-type cheese sampled $5 \mathrm{~d}$ after manufacture

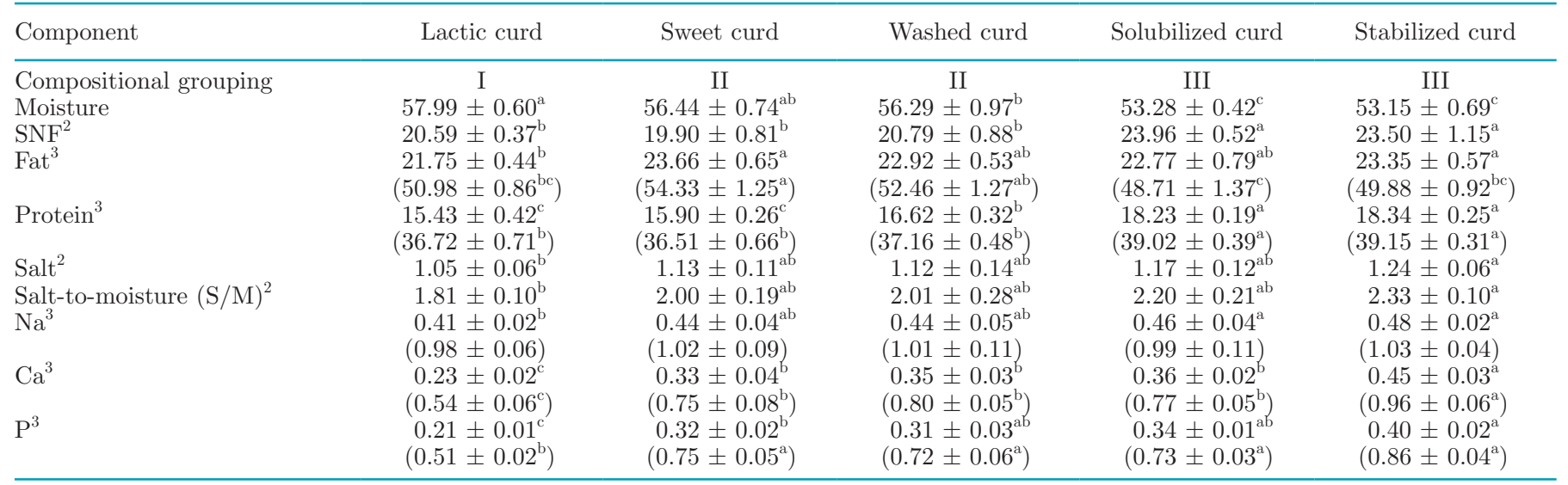

${ }^{\mathrm{a}-\mathrm{c} C h e e s e}$ composition values within a row that do not share the same superscript are significantly different $(P<0.05)$.

${ }^{1}$ Values presented are the means $\pm \mathrm{SE}$ of 2 replicate cheesemakers $(\mathrm{n}=2)$.

${ }^{2}$ Calculated values including SNF $(100 \%$ - moisture $\%$ - fat $\%)$, Salt $(\mathrm{Na} \times 2.54)$, S/M $[($ salt $\% \times 100) /$ moisture $\%]$, $\%$ on an as-is basis, protein and minerals $(\mathrm{Na}, \mathrm{Ca}$, and $\mathrm{P}$; \{attribute $\times[(100-$ moisture $\%) / 100]\}, \%$ fat on a dry basis $\{[$ attribute $/(100-$ moisture $\%)] \times 100\}$.

${ }^{3}$ Values in parentheses indicate component percentage on a dry basis.

and salt-to-moisture (1.81\%). The calcium and phosphorus contents of the lactic curd variety were the lowest (0.0.23 and $0.21 \%$, respectively).

No significant differences were observed in composition between the sweet and washed curd varieties except for protein (15.90 and $16.62 \%$, respectively). These varieties are very similar in manufacture, the only exception being starter culture quantity and the washing of the curd. The washed curd was significantly lower in moisture $(56.29 \%$ ) and it was significantly higher in protein (16.62\%) compared with lactic curd. The sweet curd was significantly higher in fat $(23.66 \%)$ compared with the lactic curd. The higher $\mathrm{pH}$ through the process led to significantly higher $(P<0.05)$ calcium content in these cheeses (sweet curd: $0.33 \%$; washed curd: $0.35 \%)$ compared with lactic curd with $(0.23 \%)$.

The solubilized and stabilized curd cheeses had no significant differences between the major compositional components. Their manufacture differed from other varieties by starter culture type, fermentation parameters, and cut size which lead to cheeses with distinct characteristics. The moisture content of these 2 varieties was significantly lower $(53.15-53.28 \%)$ than the washed curd (56.29\%) sweet curd (56.44\%), and lactic curd $(57.99 \%)$ varieties. The protein content (wt/wt and dry basis) of these 2 cheeses were the highest among the 5 varieties at $18.23-18.34 \%$ and $39.02-39.15 \%$, respectively. The calcium content of the solubilized curd $(0.36 \%)$ was comparable to the sweet curd $(0.33 \%)$ and washed curd $(0.35 \%)$ varieties, whereas the calcium content of the stabilized curd $(0.45 \%)$ was significantly higher than all other varieties. A similar pattern was seen for the phosphorous content.

\section{Lactic Curd}

Quality characteristics of lactic curd Camemberttype cheese during ripening are shown in Figure 1. The $\mathrm{pH}$ of the cheese at salting (d 0) was 4.31 (Figure 1a). Rind $\mathrm{pH}$ increased quickly achieving a $\mathrm{pH}$ of 6.98 by d 10 and a maximum $\mathrm{pH}$ of 7.92 on d 35. Increases in paste $\mathrm{pH}$ lagged, as expected, with an increase to 6.15 by $\mathrm{d} 21$. By d 50 , the $\mathrm{pH}$ of the rind and paste harmonized at 7.65 to 7.70 . The maximum firmness of the lactic curd paste started low at just $1.13 \mathrm{~N}$ on $\mathrm{d} 7$ of ripening with little difference between minimum and maximum firmness (Figure 1b). Firmness continued to decrease until d 21 and held at a very low firmness $(0.34 \mathrm{~N})$ through the end of the study (d 50). During ripening there was a change in the color, primarily the lightness $\left(\mathbf{L}^{*}\right)$ and yellow/blue coordinate $\left(\mathbf{b}^{*}\right)$ values (Figure 1c). The $\mathrm{L}^{*}$ value started at 87.19 on $\mathrm{d} 14$, and by d 50 it had decreased to 68.58 . The $\mathrm{b}^{*}$ value saw an increase over from 6.58 (d 14) to a maximum of 14.56 (d 35). The red/green coordinate $\left(\mathbf{a}^{*}\right)$ value changed only minimally from -0.43 to 1.42 . Upon cutting the lactic curd wheel at the end of ripening (d 50), paste quickly and almost completely left the rind of the lactic curd cheese (Figure 1e). The paste of the lactic curd variety spread quickly over a large distance, traveling $14 \mathrm{~mm}$ within $15 \mathrm{~min}$ after cutting (Figure 1d). The average distance of paste displacement for the lactic curd variety was not significantly different at d 35 and $50 \mathrm{~d}$ at $23.5 \mathrm{~mm}$ and $27.3 \mathrm{~mm}$, respectively, after 60 min of flow time. Taken together, these data indicate the rapid ripening of this cheese and demonstrate quality characteristics that explain its short shelf-life. 
a)

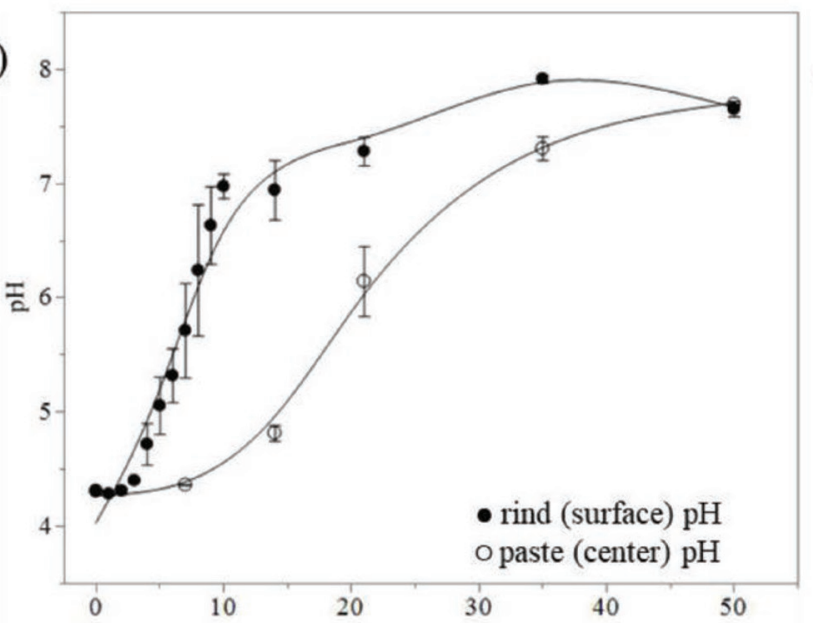

b)

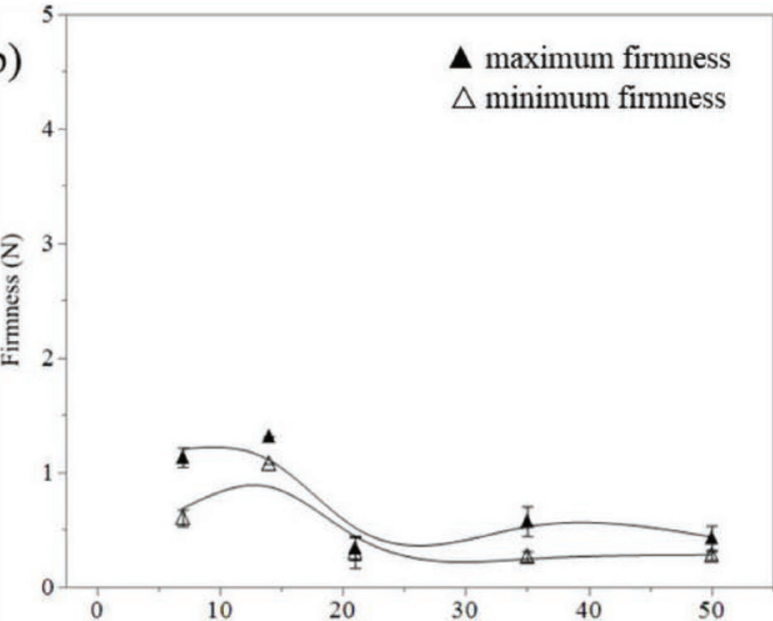

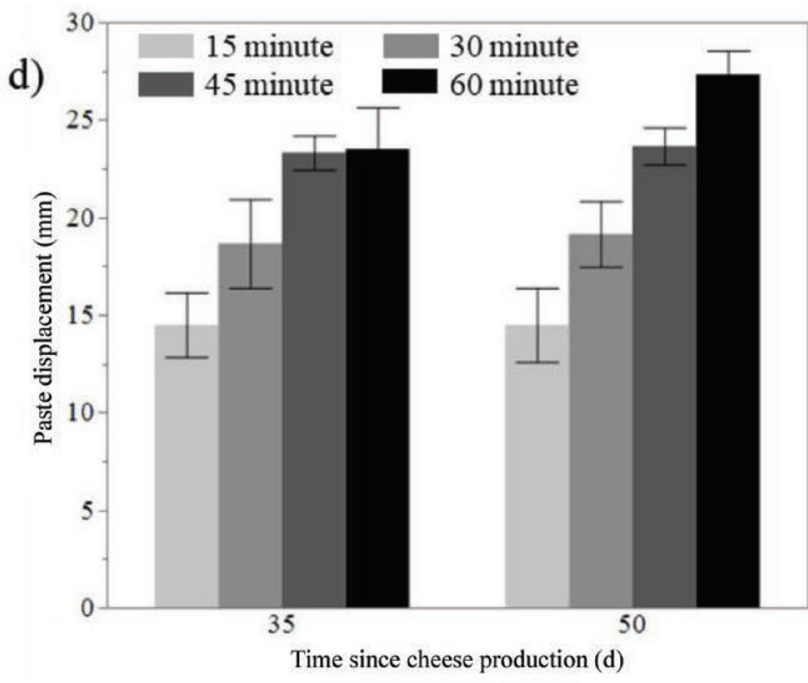

e)

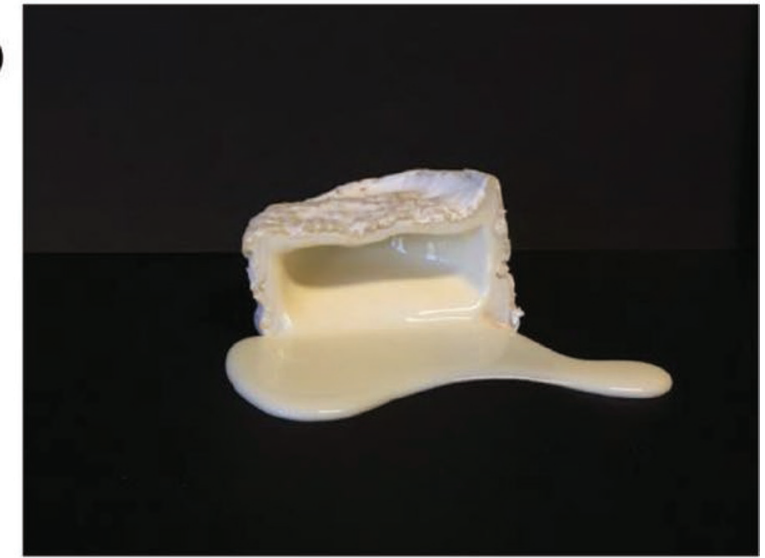

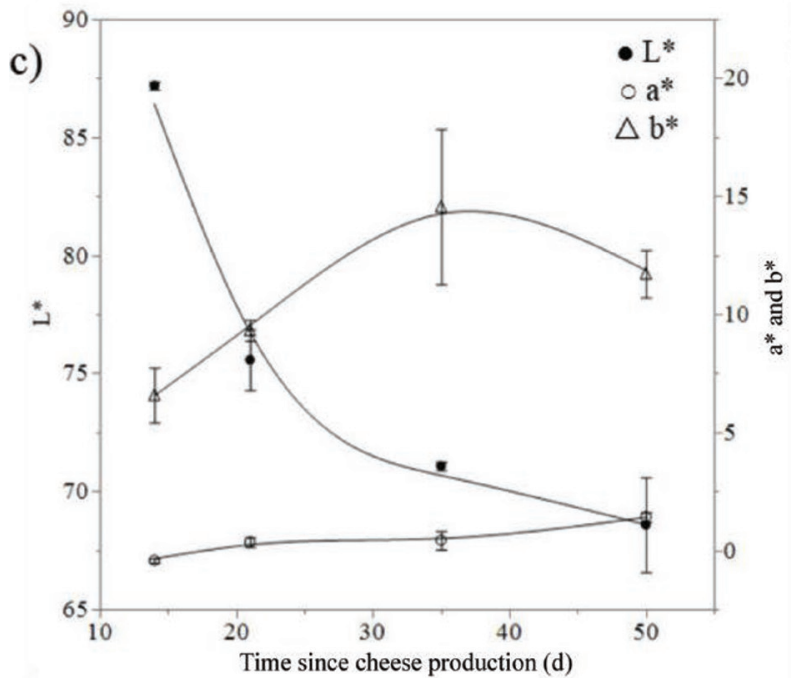

Figure 1. Characteristics of lactic curd Camembert variety from production throughout ripening $(50 \mathrm{~d})$. (a) pH of the rind and paste: rind (surface) $\mathrm{pH}(\bullet)$, and paste (center) $\mathrm{pH}(\bigcirc)$. (b) Firmness of the paste: maximum firmness $(\boldsymbol{\Lambda})$; minimum firmness (ripe zone, $\Delta$ ). (c) Color of the surface represented by lightness $\left(\mathrm{L}^{*} ; \bullet\right)$, red/green coordinate $\left(\mathrm{a}^{*} ; \bigcirc\right)$, and yellow/blue coordinate $\left(\mathrm{b}^{*} ; \Delta\right)$. (d) Paste displacement: 15,30 , 45, and $60 \mathrm{~min}$. (e) Image of the paste displacement $50 \mathrm{~d}$ into ripening at the $60 \mathrm{~min}$ time point. Error bars represent the SEM for duplicate cheese makes $(n=2)$. 


\section{Sweet Curd}

Quality characteristics of sweet curd Camemberttype cheese during ripening are shown in Figure 2. This cheese, like the lactic curd, has a short ripening period and shelf-life with substantial changes occurring between 35 and $50 \mathrm{~d}$ as demonstrated by various quality characteristics. The $\mathrm{pH}$ at salting (d 0) was 4.65 (Figure $2 \mathrm{a})$. The $\mathrm{pH}$ reached 7.38 by d 10 and the maximum of 7.85 by $\mathrm{d} 21$. The $\mathrm{pH}$ of the paste increased slowly to 5.27 by d 21 and reached a maximum of 7.53 by d 50 . This cheese was quite firm with a maximum firmness of 4.29 on $\mathrm{d} 7$ of ripening (Figure 2b). Minimum firmness of the paste was 1.91 on $\mathrm{d} 7$. The difference between the maximum and minimum decreased throughout ripening, harmonizing on d 35 at $<0.80 \mathrm{~N}$. The color of the sweet curd cheese rind slightly browned over time, with the $\mathrm{L}^{*}$ value decreasing from 82.43 to 69.13 over ripening (Figure 2c). The $\mathrm{a}^{*}$ and $\mathrm{b}^{*}$ values exhibited minor changes, ranging from 0.24 to 1.00 and 6.35 to 8.78, respectively. Paste displacement significantly increased from d 35 to 50 , averaging $11.7 \mathrm{~mm}$ on d 35 and 24.3 $\mathrm{mm}$ on d 50 after $60 \mathrm{~min}$ of flow time (Figure $2 \mathrm{~d}$ and $2 \mathrm{e})$.

\section{Washed Curd}

Quality characteristics of washed curd Camemberttype cheese during ripening are shown in Figure 3. The $\mathrm{pH}$ of the cheese at salting (d 0) was 4.80 (Figure $3 a$ ). The rind $\mathrm{pH}$ increased rapidly to 7.37 by $\mathrm{d} 10$, increased to a maximum of 7.81 by d 21 , and remained above 7.62 through $50 \mathrm{~d}$ of ripening. The $\mathrm{pH}$ of the paste was slower to increase, as expected, reaching 5.08 by $\mathrm{d} 21$ and 7.60 by $\mathrm{d} 50$. The maximum firmness of the washed curd paste was recorded on d 7 at $3.96 \mathrm{~N}$, with the minimum firmness on the same $\mathrm{d}$ at $2.14 \mathrm{~N}$. By d 35, the maximum firmness decreased to $0.65 \mathrm{~N}$, which was congruent with the minimum firmness of $0.45 \mathrm{~N}$; low firmness remained constant throughout the remaining ripening. Like the aforementioned described varieties, the $\mathrm{L}^{*}$ decreased over ripening from 84.77 to 74.07 (Figure 3c). The $\mathrm{a}^{*}$ value ranged from 0.23 to 0.70 and the $\mathrm{b}^{*}$ ranged from 6.72 to 8.22 . Upon cutting the washed curd wheel, the cheese paste moved away from the cheese wheel at a lesser extent than the sweet and lactic curd, with much of the paste remaining in the wheel (Figure 3e). The displacement distance after $60 \mathrm{~min}$ of flow time significantly increased over ripening, averaging $7.3 \mathrm{~mm}$ on $\mathrm{d} 35$ and $18.7 \mathrm{~mm}$ on d 50 (Figure 3d). The difference in paste displacement indicates that washed curd cheese undergoes much of the ripening between d 35 and 50, similar to the sweet curd variety.

\section{Solubilized Curd}

Quality characteristics of solubilized curd Camembert-type cheese during ripening are shown in Figure 4. The $\mathrm{pH}$ at salting (d 0) started at 4.95 (Figure 4a), with the rind $\mathrm{pH}$ reaching 7.29 by $\mathrm{d} 10$ and a maximum of 7.48 by $\mathrm{d} 50$. The paste $\mathrm{pH}$ increased to 5.04 by d 21 and 7.21 by d 50. Initial firmness (d 7) ranged from 2.06 to $3.41 \mathrm{~N}$ (Figure $4 \mathrm{~b}$ ). The maximum and minimum firmness continued to decrease until d 50, reaching 1.03 and $0.53 \mathrm{~N}$, respectively. The $\mathrm{L}^{*}$ value decreased over ripening like the other varieties, from 87.57 at $\mathrm{d} 7$ to 80.50 on d 50 (Figure $4 \mathrm{c}$ ). The a* value exhibited minor fluctuation from -0.06 to 0.55 . The $b^{*}$ value also remained fairly constant ranging from 6.93 to 7.56. Upon cutting the solubilized curd wheel at 50 $\mathrm{d}$, the paste remained closely associated with the wheel even after 60 min from cutting (Figure 4e). The average distance of paste displacement for the solubilized curd variety was similar at d 35 and 50 at 4 and 6 $\mathrm{mm}$, respectively, after $60 \mathrm{~min}$ of flow time (Figure $4 \mathrm{~d}$ ). These quality characteristics indicate the potential for a longer shelf-life for the solubilized curd relative to the lactic, sweet, and washed curd variants.

\section{Stabilized Curd}

Quality characteristics of stabilized curd Camemberttype cheese during ripening are shown in Figure 5. The $\mathrm{pH}$ of the cheese at salting ( $\mathrm{d} 0$ ) was the highest of all varieties at 5.24 (Figure 5a). The rind $\mathrm{pH}$ increased to 7.10 by d 10 and reached a maximum by d 50 of 7.52 . The $\mathrm{pH}$ of the paste was slower to increase reaching 5.30 by $\mathrm{d} 21$ and 7.36 by d 50 . The initial maximum firmness of the stabilized curd was quite low at $2.51 \mathrm{~N}$ on $\mathrm{d} 7$, whereas the minimum firmness was 1.70 on $\mathrm{d} 7$ (Figure 5b). The firmness decreased over ripening, with the largest decrease happening between d 35 and 50 . The maximum firmness on $\mathrm{d} 50$ was $1.35 \mathrm{~N}$ whereas the minimum was $0.78 \mathrm{~N}$. Like the other varieties, the $\mathrm{L}^{*}$ value decreased over ripening from 83.75 to 77.58 (Figure $5 \mathrm{c}$ ). The $\mathrm{a}^{*}$ value ranged from -0.16 to 0.76 . The $\mathrm{b}^{*}$ value remained relatively unchanged, ranging from 5.97 to 6.96 . After the wheel was cut, the cheese paste moved very little over the $60 \mathrm{~min}$ as shown in Figure 5e. The displacement distance after $60 \mathrm{~min}$ of flow time was $3 \mathrm{~mm}$ on d 35 and $4.3 \mathrm{~mm}$ on d 50 (Figure $5 \mathrm{~d}$ ). Considering these physical quality characteristics, the stabilized curd variety would have the longest shelf-life of the varieties evaluated in this study.

\section{DISCUSSION}

Camembert recipe variations result in the production of cheeses that differ substantially in their composi- 

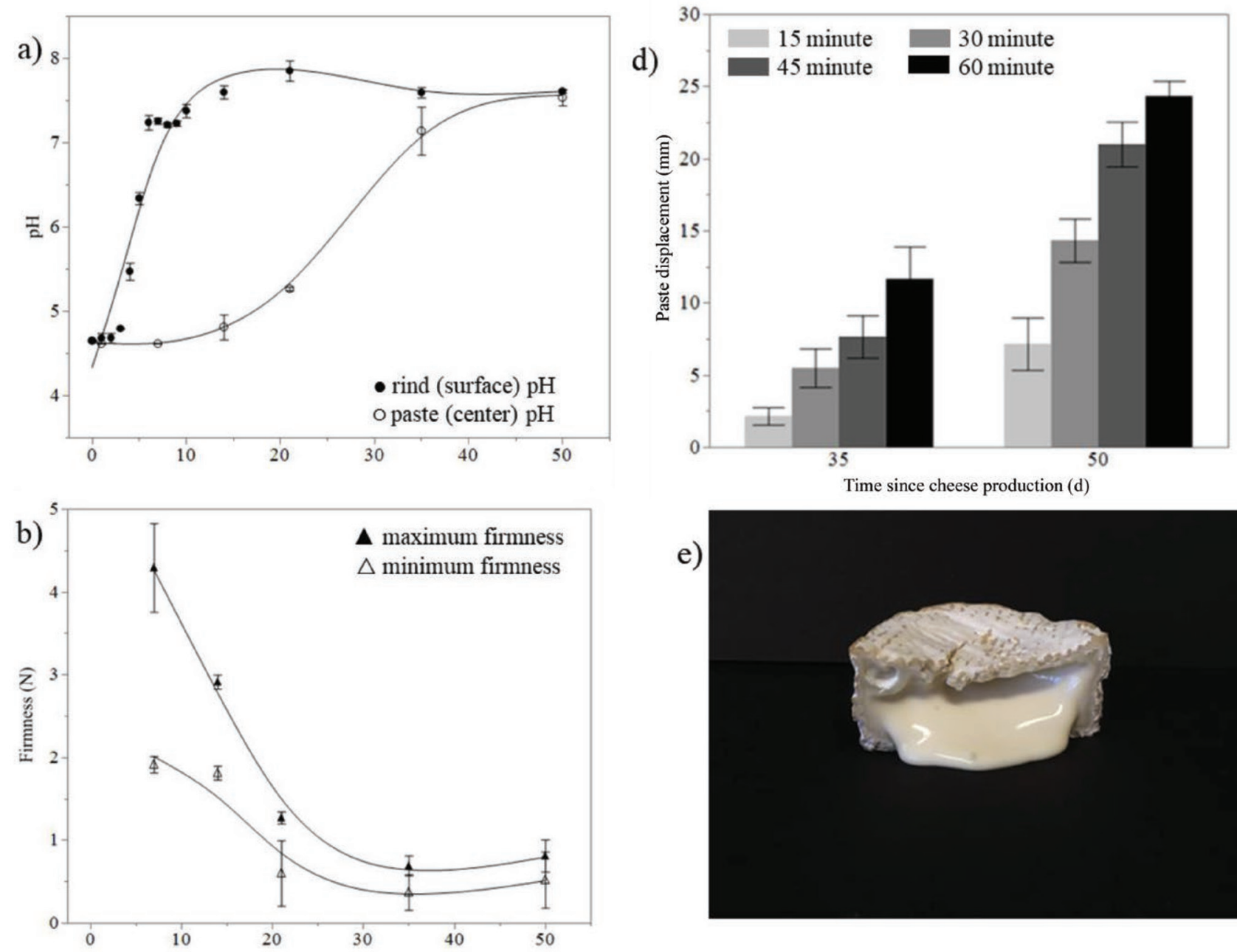

e)
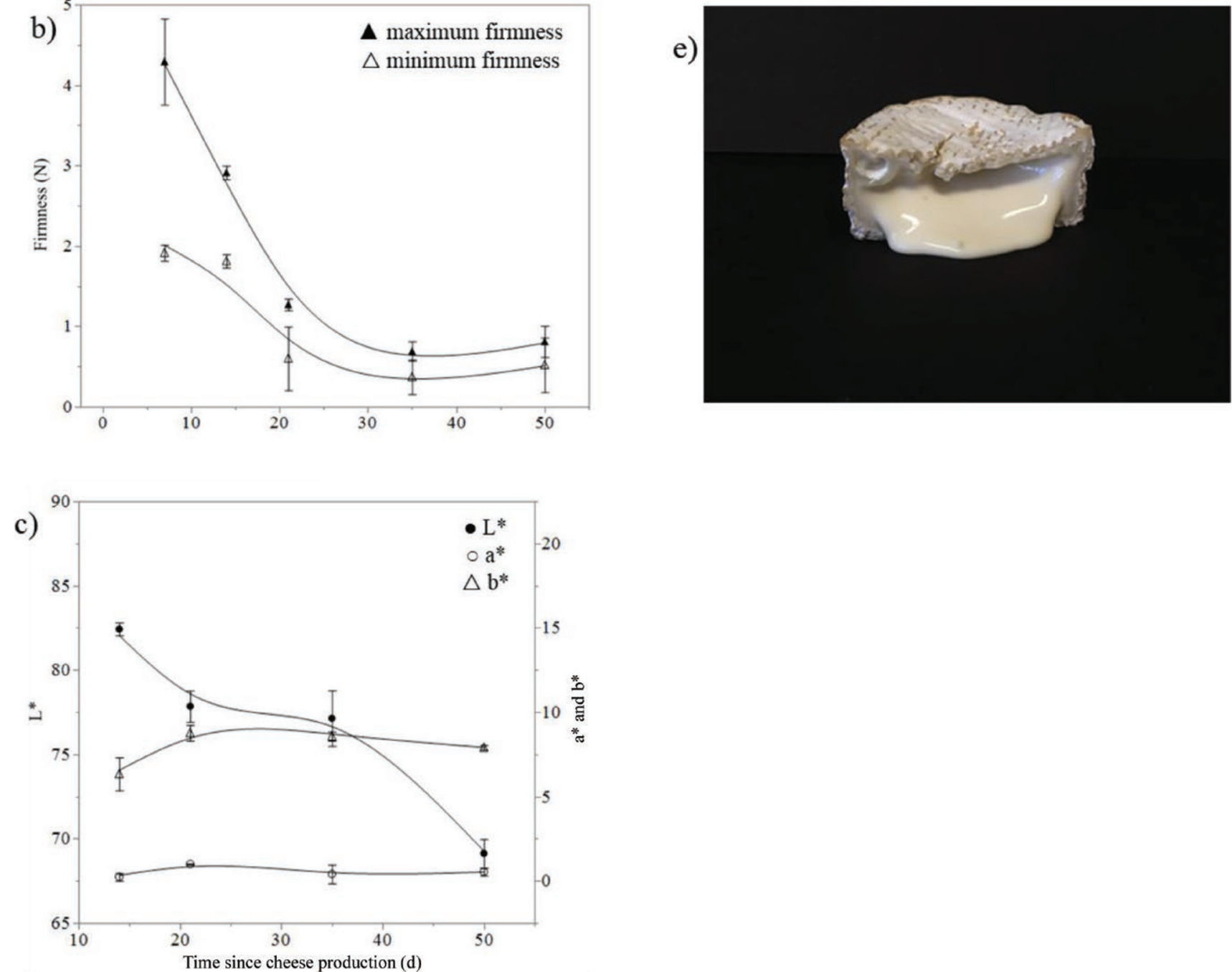

Figure 2. Characteristics of sweet curd Camembert variety from production throughout ripening $(50 \mathrm{~d})$. (a) pH of the rind and paste: rind (surface) $\mathrm{pH}(\bullet)$, and paste (center) $\mathrm{pH}(\bigcirc)$. (b) Firmness of the paste: maximum firmness $(\boldsymbol{\Lambda})$; minimum firmness (ripe zone, $\Delta$ ). (c) Color of the surface represented by lightness $\left(\mathrm{L}^{*} ; \bullet\right)$, red/green coordinate $\left(\mathrm{a}^{*} ; \mathrm{O}\right)$, and yellow/blue coordinate $\left(\mathrm{b}^{*} ; \Delta\right)$. (d) Paste displacement: 15,30 , 45, and $60 \mathrm{~min}$. (e) Image of the paste displacement $50 \mathrm{~d}$ into ripening at the $60 \mathrm{~min}$ time point. Error bars represent the SEM for duplicate cheese makes $(\mathrm{n}=2)$. 
a)

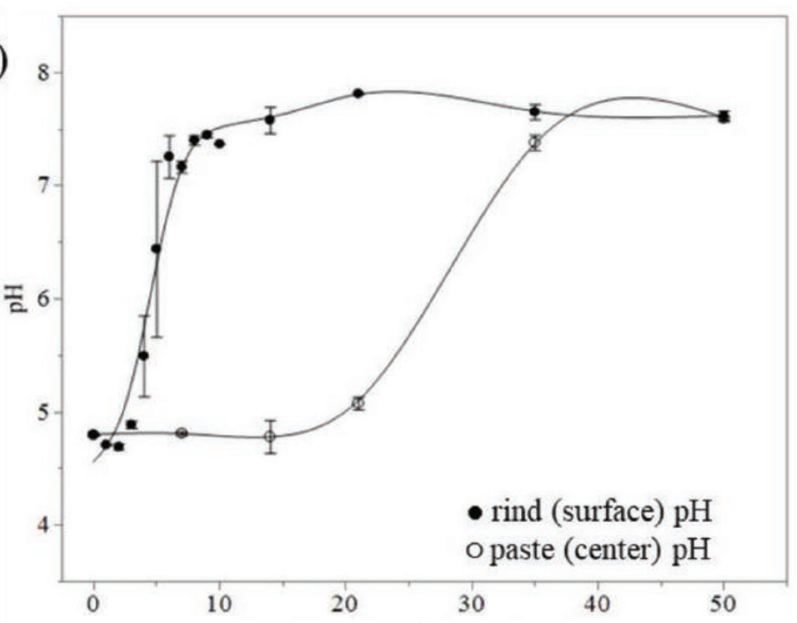

b)

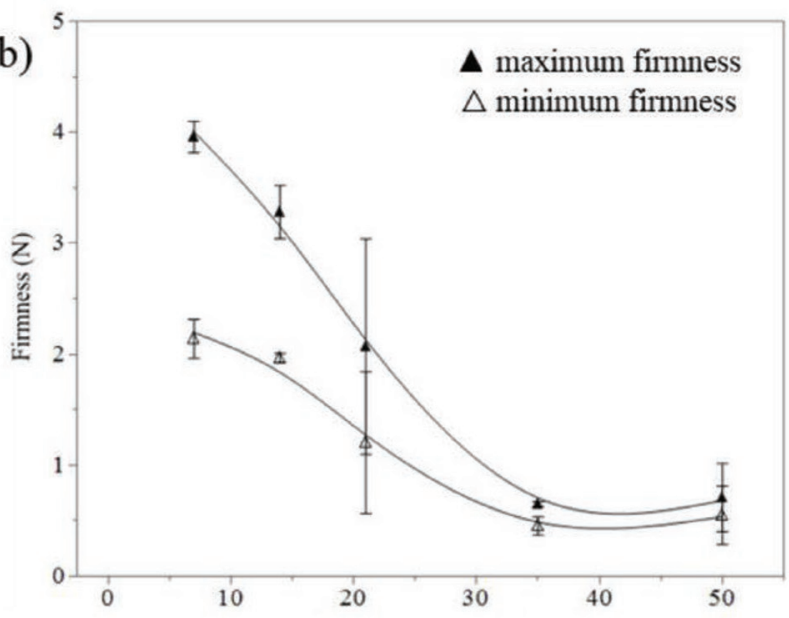

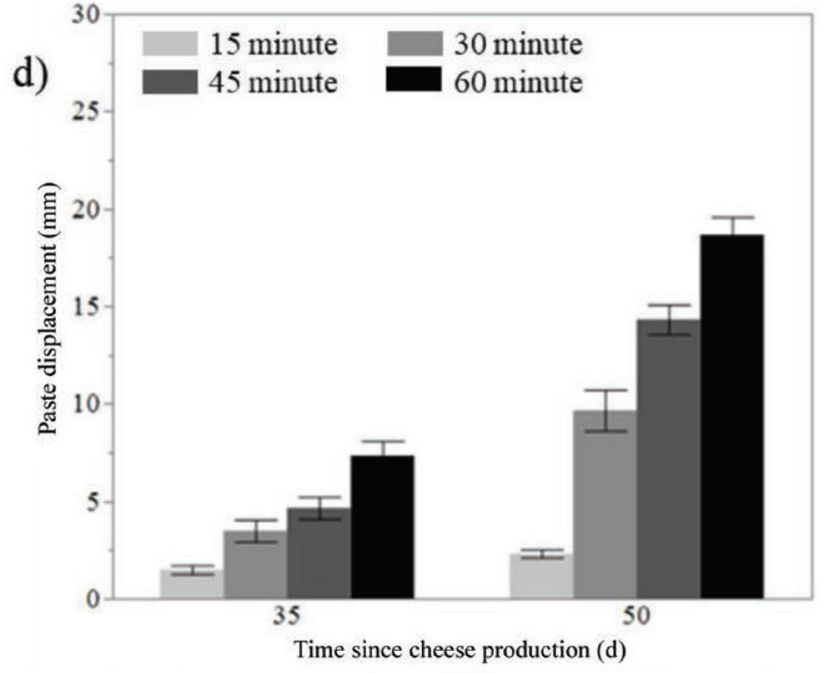

e)

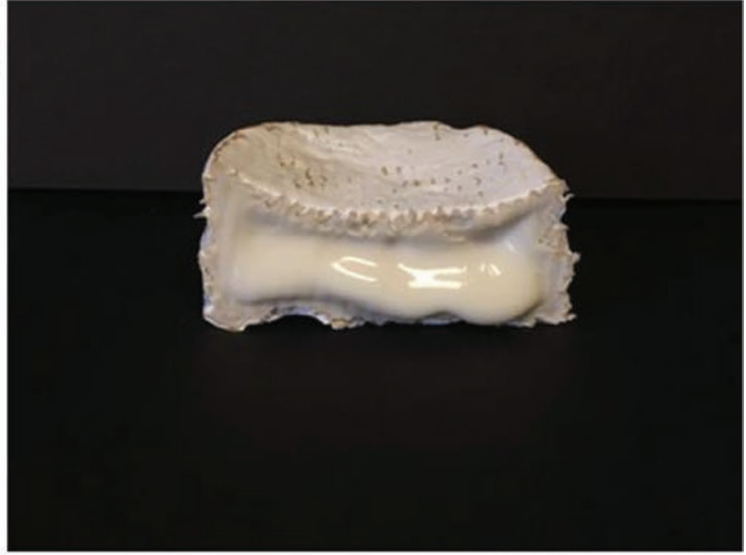

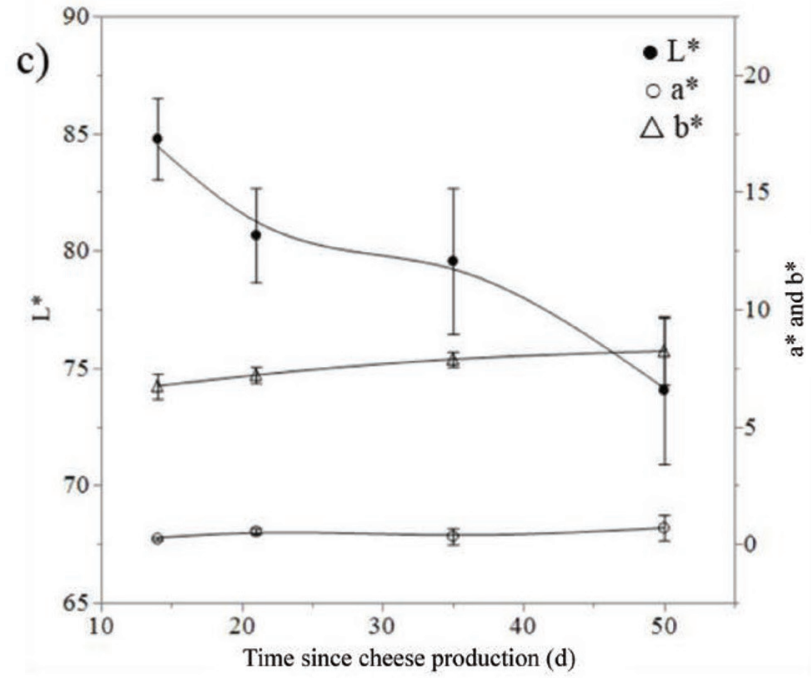

Figure 3. Characteristics of washed curd Camembert variety from production throughout ripening (50 d). (a) pH of the rind and paste: rind (surface) $\mathrm{pH}(\bullet)$, and paste (center) $\mathrm{pH}(\mathrm{O})$. (b) Firmness of the paste: maximum firmness $(\mathbf{\Delta})$; minimum firmness (ripe zone, $\Delta$ ). (c) Color of the surface represented by lightness $\left(\mathrm{L}^{*} ; \bullet\right)$, red/green coordinate $\left(\mathrm{a}^{*} ; \mathrm{O}\right)$, and yellow/blue coordinate $\left(\mathrm{b}^{*} ; \Delta\right)$. (d) Paste displacement: 15, 30, 45, and $60 \mathrm{~min}$. (e) Image of the paste displacement $50 \mathrm{~d}$ into ripening at the $60 \mathrm{~min}$ time point. Error bars represent the SEM for duplicate cheese makes $(\mathrm{n}=2)$. 

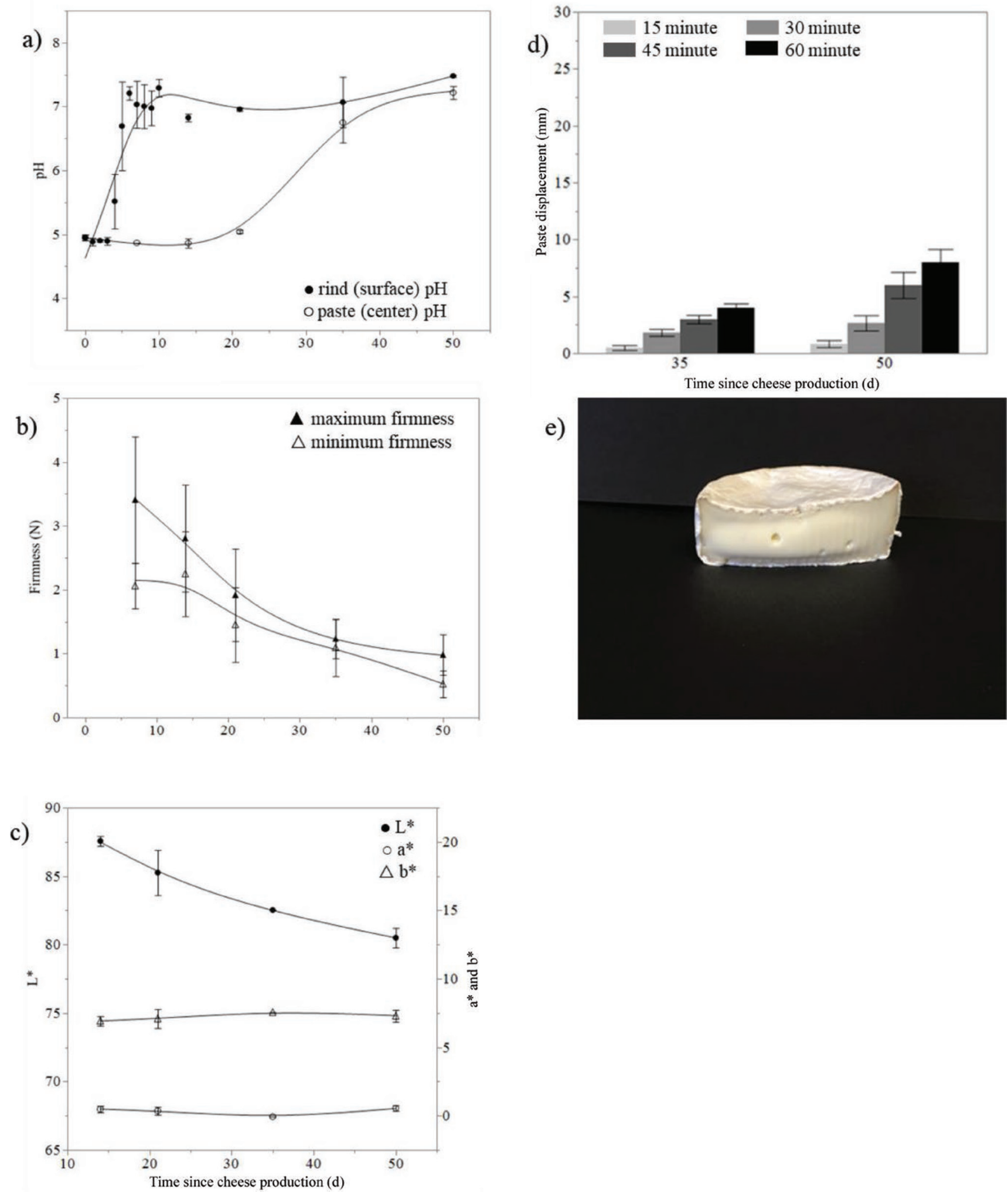

Figure 4. Characteristics of solubilized curd Camembert variety from production throughout ripening (50 d). (a) pH of the rind and paste: rind (surface) $\mathrm{pH}(\bullet)$, and paste (center) $\mathrm{pH}(\mathrm{O})$. (b) Firmness of the paste: maximum firmness $(\boldsymbol{\Delta})$; minimum firmness (ripe zone, $\Delta$ ). (c) Color of the surface represented by lightness $\left(\mathrm{L}^{*} ; \boldsymbol{\bullet}\right)$, red/green coordinate $\left(\mathrm{a}^{*} ; \mathrm{O}\right)$, and yellow/blue coordinate $\left(\mathrm{b}^{*} ; \Delta\right)$. (d) Paste displacement: 15 , 30, 45, and $60 \mathrm{~min}$. (e) Image of the paste displacement $50 \mathrm{~d}$ into ripening at the 60 min time point. Error bars represent the SEM for duplicate cheese makes $(\mathrm{n}=2)$. 

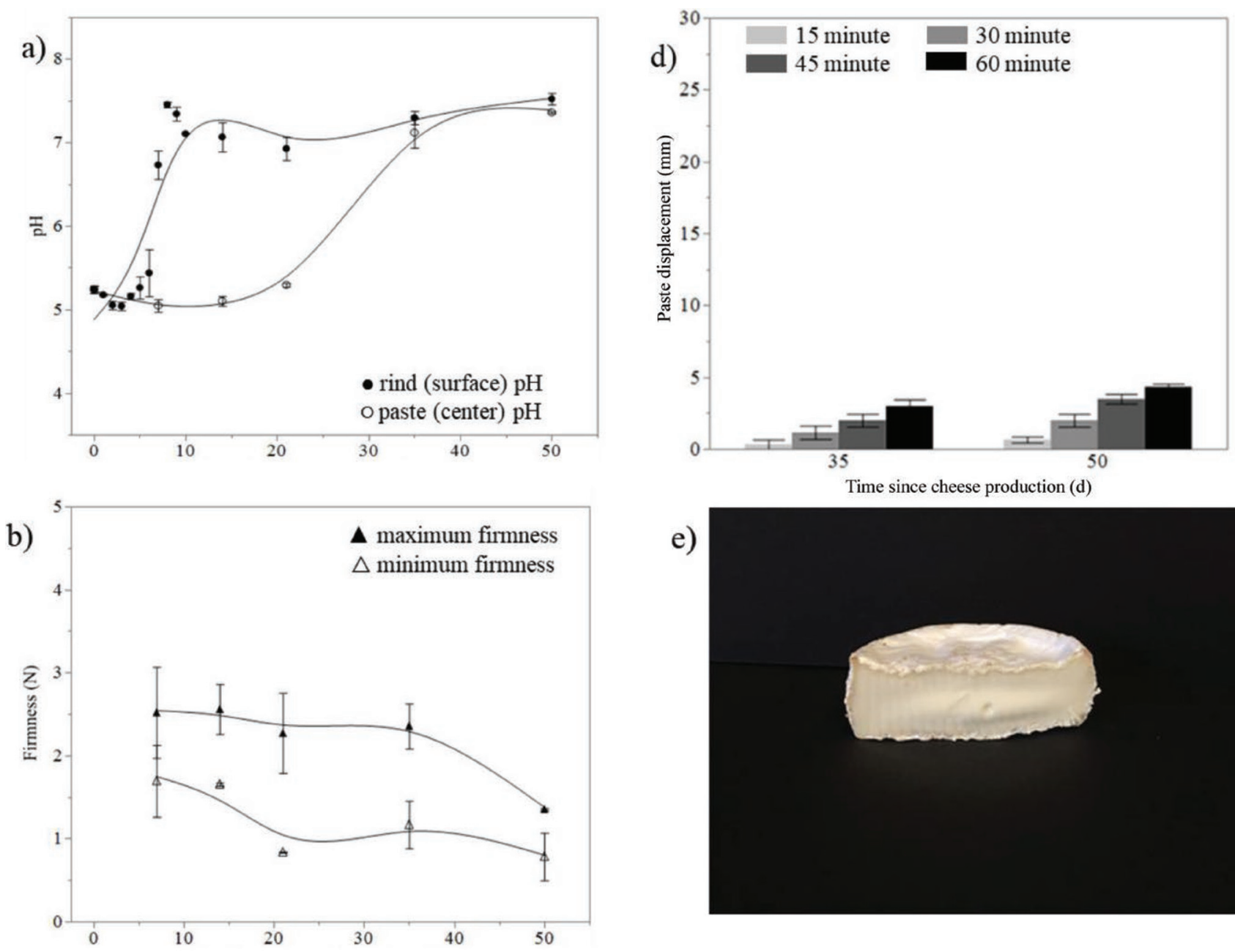

e)

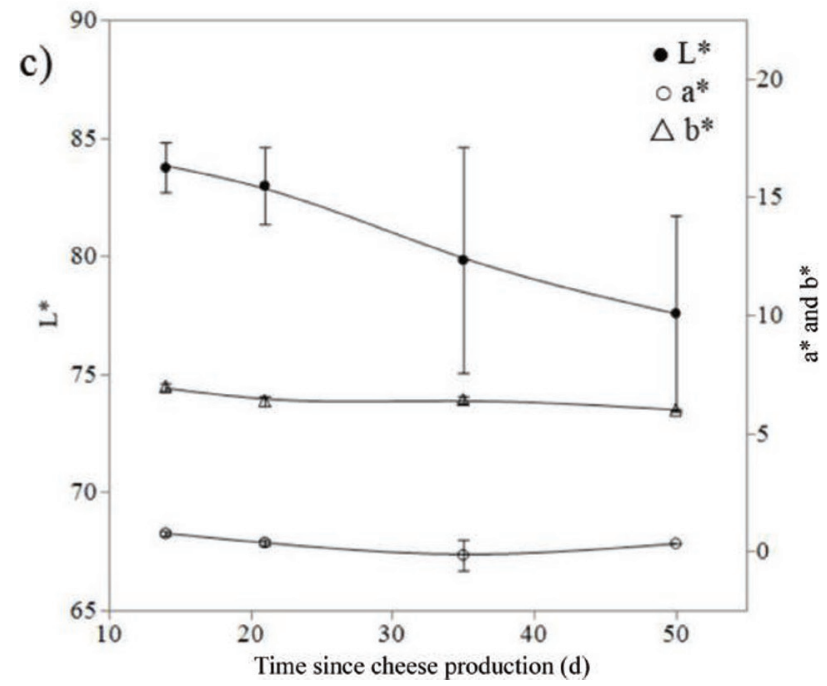

Figure 5. Characteristics of stabilized curd Camembert variety from production throughout ripening (50 d). (a) pH of the rind and paste: rind (surface) $\mathrm{pH}(\bullet)$, and paste (center) $\mathrm{pH}(\mathrm{O})$. (b) Firmness of the paste: maximum firmness $(\mathbf{\Lambda})$; minimum firmness (ripe zone, $\Delta$ ). (c) Color of the surface represented by lightness $\left(\mathrm{L}^{*} ; \mathbf{\bullet}\right)$, red/green coordinate $\left(\mathrm{a}^{*} ; \mathrm{O}\right)$, and yellow/blue coordinate $\left(\mathrm{b}^{*} ; \Delta\right)$. (d) Paste displacement: 15 , 30, 45, and $60 \mathrm{~min}$. (e) Image of the paste displacement $50 \mathrm{~d}$ into ripening at the $60 \mathrm{~min}$ time point. Error bars represent the SEM for duplicate cheese makes $(\mathrm{n}=2)$. 
tion and a variety of quality characteristics throughout ripening. In this study, we produced Camembert-type cheeses using 5 different recipes. All recipes produced cheeses that had a composition representative of Camembert-type cheese early in ripening (Schlesser et al., 1992; Kulmyrzaev et al., 2005). The salting procedure or the alternative method used to calculate salt in this study resulted in salt levels that were slightly lower than expected; however, this was consistent across all cheese varieties. Comparing the $\mathrm{Na}$ (dry weight basis) content to that of the commercial cheeses studied by Tansman et al. (2017), the content was quite similar.

The alternative processes (as compared with the traditional lactic curd recipe) resulted in Camembert-type cheeses with varying curd type, composition, and quality. The traditional lactic curd cheese relies on acidification as the catalyst for gel formation, whereas alternative recipes limit acidification and drive enzymatic coagulation through the addition of rennet. Washed curd, solubilized curd, and stabilized curd varieties had an elevated $\mathrm{pH}$ compared with the other curd types, which likely contributed to improved paste stability; however, only through the use of a thermophilic starter (stabilized curd variety in this study) were we able to achieve the desired $\mathrm{pH}$ at salting for a stabilized type cheese (of $\geq 5.2$ ). Paste stabilization was also likely affected by the use of a mixed starter (thermophilic/ mesophilic), and curd washing to limit acid production by the starter culture.

Shelf-life of Camembert cheese is largely a function of texture deterioration. Texture stability in Camembert cheese recipes was correlated with increasing calcium content in young cheeses. Lactic curd had the lowest initial total calcium content $(0.23 \%)$ and resulted in the least stable texture throughout shelf life. At $50 \mathrm{~d}$, this cheese paste nearly liquefied as demonstrated by the lack of cheese remaining in the rind during the paste displacement test (Figure 1e). Substantial improvement in texture stability was apparent when total Ca content was increased, leading to Ca concentrations of $\geq 0.33 \%$. Calcium concentration in the young cheeses differed as a function of $\mathrm{pH}$ at salting and throughout the cheese make. Higher $\mathrm{pH}$ at this stage and throughout the cheesemaking process increases the insoluble colloidal calcium phosphate content and overall interactions with casein (Keller et al., 1974; Lucey et al., 2003) leading to a decrease in flowability and an overall more stable cheese paste. While all recipes with higher total $\mathrm{Ca}$ showed improved texture stability, the stabilized curd with the highest $\mathrm{pH}$ at salting $(\mathrm{pH} 5.2-5.3)$ and highest total Ca content $(0.45 \%)$ showed little softening and minimal paste displacement (flow) by d 50 . The optimum time for consumption of this cheese would be $>50$ $\mathrm{d}$ of ripening.
The $\mathrm{pH}$ throughout the process controlled the final total $\mathrm{Ca}$ in the cheese. Across the 5 varieties of Camembert-type cheese the degree of acidification during the make varied significantly with the $\mathrm{pH}$ at salting ranging from 4.3 to 5.3. Total Ca content trend for all cheeses was directly related to the $\mathrm{pH}$ at salting and inversely related to the total degree of acidification. It has been previously reported that 3 main factors affect demineralization during cheese manufacture including milk preacidification, $\mathrm{pH}$ during draining, and degree of cooking (Lucey and Fox, 1993). In this study, multiple methods were used to control $\mathrm{pH}$ and ultimately $\mathrm{Ca}$ content. This included $\mathrm{pH}$ at rennet addition, quantity of starter culture added, type of starter culture used, fermentation temperature, and washing of the curd. These process modifications limited the degree of acidification during draining, and ultimately were successful in controlling total retained $\mathrm{Ca}$ in the cheeses. Similar methods for controlling $\mathrm{Ca}$ content have previously been used for mozzarella, Cheddar, and Colby cheeses (Guinee et al., 2002; Upreti and Metzger, 2006; Lee et al., 2010). The cut size was also modified $(1 \mathrm{~cm}$ cubes) for the stabilized and solubilized as described by Spinnler and Gripon (2004) when referring to the manufacturing methods for stabilized cheeses. This was done to achieve an acceptable moisture content as the large cut size decreased whey expulsion during draining. This was likely due to the lesser degree of syneresis occurring at a higher $\mathrm{pH}$ (Lund et al., 1971; Walstra, 1993).

This study was designed to characterize the compositional and quality characteristics of Camembert cheeses produced by differing methods currently used by Camembert-type cheesemakers. This study was not designed to systematically evaluate the effect of individual modifications; however, these results suggest how modifications in specific cheese making processes influence important cheese quality outcomes. It is also important to note, that all cheeses in this study were of a single diameter $(7 \mathrm{~cm})$. Camembert cheese diameter and height will influence the rate of ripening and related quality characteristics; nevertheless, the mechanism for bloomy rind cheese ripening and relative performance of recipes should be the same regardless of cheese size.

\section{CONCLUSIONS}

This study demonstrated significant differences in product composition as well as the $\mathrm{pH}$ changes, texture/cheese body, and color development during ripening of 5 Camembert-type cheese variants. The study provides the framework of different procedures that can be used to make Camembert-type cheese and the effect these recipe variants will have on the quality and shelf 
life of the cheese. Understanding how different Camembert-type cheese making recipes influence cheese composition will assist cheesemakers in controlling final product quality and allow them to manufacture cheese that will meet the desired expectations of the consumer and requirements for their distribution network.

\section{ACKNOWLEDGMENTS}

The authors thank the many parties that contributed to the completion of this study. We thank Neville McNaughton for the cheese recipe inspiration. We also thank Yanyun Zhao's laboratory members, especially Zilong Deng and Jooyeoun Jung, for analytical support (Oregon State University, Corvallis). We very much appreciate the help with cheese making and analysis from Eva Kuhn, Danica Berry, Alex Emch, Robin Frojen, and the Arbuthnot Dairy Center (Oregon State University, Corvallis) team. Funding for this study was supported by Dairy Management Inc. (Rosemont, IL) and the Charles E. and Clara Marie Eckelman Fellowship.

\section{REFERENCES}

Abraham, S., R. Cachon, B. Colas, G. Feron, and J. De Coninck. 2007. Eh and $\mathrm{pH}$ gradients in Camembert cheese during ripening: Measurements using microelectrodes and correlations with texture. Int. Dairy J. 17:954-960. https://doi.org/10.1016/j.idairyj .2006.12.010.

American Cheese Society. 2016. State of the US Artisan/Specialty Cheese Industry. Accessed Jan. 14, 2018. http:// 1sskha48hhbhl0oc61bhsagh.wpengine.netdna-cdn.com/wp -content/uploads/2017/02/2016-State-of-the-US-Artisan-and -Specialty-Cheese-Industry-Summary-Report.pdf.

American Cheese Society. 2018. ACS \& Industry Growth. Accessed Jan. 14, 2018. http://www.cheesesociety.org/membership/the-acs -universe/.

Bouma, A., C. A. Durham, and L. Meunier-Goddik. 2014. Start-up and operating costs for artisan cheese companies. J. Dairy Sci 97:3964-3972. https://doi.org/10.3168/jds.2013-7705.

Buragas, A. 2006. Brie, Camembert Bring Royal Heritage to U.S. Cheese Market. Accessed Dec. 19, 2017. http://www.cheesemarketnews .com/articlearch/cheese/27oct06_02.html.

Galli, B. D., J. G. P. Martin, P. P. M. da Silva, E. Porto, and M. H F. Spoto. 2016. Sensory quality of Camembert-type cheese: Relationship between starter cultures and ripening molds. Int. J. Food Microbiol. 234:71-75. https://doi.org/10.1016/j.ijfoodmicro.2016 .06 .025

Gripon, J. C. 1997. Flavour and Texture in Soft Cheese. 2nd ed. B. A. Law, ed. Springer Science \& Business Media, Berlin, Germany.

Guinee, T. P., E. P. Feeney, M. A. Auty, and P. F. Fox. 2002. Effect of $\mathrm{pH}$ and calcium concentration on some textural and functional properties of mozzarella cheese. J. Dairy Sci. 85:1655-1669. https: //doi.org/10.3168/jds.S0022-0302(02)74238-0.

International Organization for Standardization (ISO). 2008. Cheese Determination of fat content. Van Gulik method. ISO Standard 3433. International Organization for Standardization, Geneva, Switzerland.
Karahadian, C., and R. C. Lindsay. 1987. Integrated roles of lactate, ammonia, and calcium in texture development of mold surfaceripened cheese. J. Dairy Sci. 70:909-918. https://doi.org/10.3168/ jds.S0022-0302(87)80094-2.

Keller, B., N. F. Olson, and T. Richardson. 1974. Mineral retention and rheological properties of Mozzarella cheese made by direct acidification. J. Dairy Sci. 57:174-180. https://doi.org/10.3168/ jds.S0022-0302(74)84856-3.

Kulmyrzaev, A., É. Dufour, Y. Noël, M. Hanafi, R. Karoui, E. M. Qannari, and G. Mazerolles. 2005. Investigation at the molecular level of soft cheese quality and ripening by infrared and fluorescence spectroscopies and chemometrics-Relationships with rheology properties. Int. Dairy J. 15:669-678. https://doi.org/10.1016/ j.idairyj.2004.08.016.

Lawrence, R. C., L. K. Creamer, and J. Gilles. 1987. Texture development during cheese ripening. J. Dairy Sci. 70:1748-1760. https:// doi.org/10.3168/jds.S0022-0302(87)80207-2.

Le Graet, Y., A. Lepienne, G. Brule, and P. Ducruet. 1983. Migration du calcium et des phosphates inorganiques dans les fromages à pâte molle de type Camembert au cours de l'affinage. Lait 63:317332. https://doi.org/10.1051/lait:1983629-63019.

Leclercq-Perlat, M.-N. 2011. Camembert, Brie, and Related Varieties. Encycl. Dairy Sci. 773-782. https://doi.org/10.1016/B978-0 -12-374407-4.00091-1.

Lee, M.-R., M. E. Johnson, S. Govindasamy-Lucey, J. J. Jaeggi, and J. A. Lucey. 2010. Insoluble calcium content and rheological properties of Colby cheese during ripening. J. Dairy Sci. 93:1844-1853. https://doi.org/10.3168/jds.2009-2734.

Lucey, J. A., and P. F. Fox. 1993. Importance of calcium and phosphate in cheese manufacture: A review. J. Dairy Sci. 76:1714-1724. https://doi.org/10.3168/jds.S0022-0302(93)77504-9.

Lucey, J. A., M. E. Johnson, and D. S. Horne. 2003. Invited Review: Perspectives on the basis of the rheology and texture properties of cheese. J. Dairy Sci. 86:2725-2743. https://doi.org/10.3168/jds .S0022-0302(03)73869-7.

Lund, D. B., N. F. Olson, and M. C. Patel. 1971. Factors affecting syneresis of renneted milk gels. J. Dairy Sci. 55:913-918. https:// doi.org/10.3168/jds.S0022-0302(72)85596-6.

Schlesser, J. E., S. J. Schmidt, and R. Speckman. 1992. Characterization of chemical and physical changes in Camembert cheese during ripening. J. Dairy Sci. 75:1753-1760. https://doi.org/10.3168/jds .S0022-0302(92)77934-X.

Shaw, M. B. 1981. The manufacture of soft, surface mould, ripened cheese in France with particular reference to Camembert. J. Soc. Dairy Technol. 34:131-138.

Sousa, M. J. 2003. Cheeses|Surface Mold-ripened Cheese Varieties. Encycl. Food Sci. Nutr. 1122-1129. https://doi.org/10.1016/B0-12 $-227055-\mathrm{X} / 00807-5$.

Spinnler, H.-E., and J.-C. Gripon. 2004. Surface mould-ripened cheeses. Cheese: Chemistry. Physics and Microbiology. 2:157-174.

Tansman, G. F., P. S. Kindstedt, and J. M. Hughes. 2017. Crystallization and demineralization phenomena in stabilized white mold cheese. J. Dairy Sci. 100:6074-6083. https://doi.org/10.3168/jds .2016-12259.

Upreti, P., and L. E. Metzger. 2006. Influence of calcium and phosphorus, lactose, and salt-to-moisture ratio on Cheddar cheese quality: Manufacture and composition. J. Dairy Sci. 89:420-428. https:// doi.org/10.3168/jds.S0022-0302(06)72106-3.

Walstra, P. 1993. The syneresis of curd. Cheese Chem. Phys. Microbiol. 141-191. https://doi.org/10.1007/978-1-4615-2650-6_5.

Wiles, P. G., I. K. Gray, and R. C. Kissling. 1998. Routine analysis of proteins by Kjeldahl and Dumas methods: Review and interlaboratory study using dairy products. J. AOAC Int. 81:620-632.

Wisconsin Milk Marketing Board. 2017. 2017 Dairy Data. Accessed Jan. 9, 2018. http://www.wisconsindairy.org/assets/images/pdf/ WisconsinDairyData.pdf. 